\title{
Inept drug supply management causing stock-outs
}

口ifㅇㅁㅁ Poor drug supply chain 14. management by inappropriately skilled provincial 口保证 officials - not the 'red herring' of manufacturer supply issues cited by national health minister Dr Aaron Motsoaledi - is primarily responsible for massive medi- cine stock-out problems in the public health system.

This is the conclusion reached by Ground Up, a community news organisation focusing on social justice stories in vulnerable communities, and the Treatment Action Campaign (TAC) and its Stop Stock Outs advocacy campaign. Verifying claims made in three identically labelled anonymous letters detailing stock-outs in healthcare facilities in KwaZulu-Natal (KZN) (reflecting widespread pockets of dysfunction nationally), Ground Up said that items included basic over-thecounter medicines such as paracetamol. As of 10 June this year, King Edward VIII Hospital had 389 line items out of stock, 
Northdale Hospital 200, Grey’s Hospital 132, Ladysmith Provincial Hospital 191, East Street Clinic 96, and Imbalenhle Clinic 159, the last facility stock-out count having been taken on 5 June. Sterile water for inhalation, alcohol and eyedrops were absent, as were various antibiotics, some antiretrovirals and some doses of fluconazole, an essential drug used to treat two potentially lethal opportunistic infections associated with HIV. Several products used for the management and treatment of tuberculosis were also out of stock across most facilities.

The whistle blowers, who insisted on anonymity, said that veiled threats had been made against them for speaking out, citing a 'henchman in a big, pricey suit and pointy shoes, talking the whole time on his cell phone' who came to their facility from the National Department of Health (NDoH). The man reportedly told them that the national health minister 'knows the names' of the doctors who were reporting stockouts. They qualified their complaints by saying that the $\mathrm{NDoH}$ was 'trying to get it right' but was hamstrung by provincial dysfunction, while health workers were innovatively sourcing alternative drugs using the private sector. Yet provincial medicine depots continued to fail hospitals and clinics because of poor stock level maintenance, poor processing of orders and dismal distribution.

A national audit by Stop Stock Outs last year found that only $20 \%$ of reported cases were caused by manufacturing issues. The remaining $80 \%$ were attributed to management and logistical challenges between the medicine depot and clinics at both provincial and district levels. These included incorrect quantities of drugs being ordered by clinics, inaccurate forecasting of drugs per population, and poor stock management at facility level. Marcus Low, head of policy at the TAC, said that the $\mathrm{NDoH}$ keeps shifting the focus to international supply shortages, but this is a red herring. He said drugs such as penicillin and abacavir were the exception, as they were facing actual supply problems. 'To deal with this crisis we must address the underlying problems of poor management, cadre deployment and under-investment in medicines distribution,' he stressed.

Motsoaledi has repeatedly cited problems with suppliers and even referred to an international report showing that we are not the only country that has shortages. Responding to the latest specific KZN revelations, Motsoaledi said: 'It is quite unfortunate that this whole saga emerged from KZN, because this is one of two provinces where we are piloting. KZN in particular is fully covered by the new cell phone technology that traces drug stock-outs right up to facility level.' In his closing speech at the South African AIDS Conference on 12 June, Motsoaledi admitted that when drugs are not out of stock internationally and are still being manufactured, the problem lay with logistics. 'I never denied, I never ran away', he added.

\section{Chris Bateman}

chrisb@hmpg.co.za

S Afr Med J 2015;105(7):706-707.

DOI:10.7196/SAMJnew.8543 